Fall 10-2009

\title{
Toward evidence-based teaching: evaluating the effectiveness of two teaching strategies in an associate degree nursing program
}

\author{
Lori S. Lauver, PhD, RN \\ Thomas Jefferson School of Nursing \\ Margaret M. West, PhD, RN \\ Thomas Jefferson School of Nursing \\ Timothy B. Campbell, MSN, CRNP \\ Thomas Jefferson School of Nursing \\ Jennifer Herrold, MSN, CRNP \\ Thomas Jefferson School of Nursing \\ Folfow WRRSand 1 addditional works at: https://jdc.jefferson.edu/nursfp \\ Geisinger Medical Center \\ Part of the Nursing Commons

\section{Let us know how access to this document benefits you}

\section{Recommended Citation}

Lauver, PhD, RN, Lori S.; West, PhD, RN, Margaret M.; Campbell, MSN, CRNP, Timothy B.; Herrold, MSN, CRNP, Jennifer; and Wood, MS, G. C, "Toward evidence-based teaching: evaluating the effectiveness of two teaching strategies in an associate degree nursing program" (2009). College of Nursing Faculty Papers \& Presentations. Paper 22.

https://jdc.jefferson.edu/nursfp/22

This Article is brought to you for free and open access by the Jefferson Digital Commons. The Jefferson Digital Commons is a service of Thomas Jefferson University's Center for Teaching and Learning (CTL). The Commons is a showcase for Jefferson books and journals, peer-reviewed scholarly publications, unique historical collections from the University archives, and teaching tools. The Jefferson Digital Commons allows researchers and interested readers anywhere in the world to learn about and keep up to date with Jefferson scholarship. This article has been accepted for inclusion in College of Nursing Faculty Papers \& Presentations by an authorized administrator of the Jefferson Digital Commons. For more information, please contact: JeffersonDigitalCommons@jefferson.edu. 


\title{
As submitted to:
}

Teaching and Learning in Nursing and later published as:

\section{"Toward evidence-based teaching: evaluating the effectiveness of two teaching strategies in an associate degree nursing program" Teaching and Learning in Nursing}

\section{Volume 4, Issue 4, October 2009, Pages 133-138 \\ DOI: 10.1016/j.teln.2009.03.001}

\begin{abstract}
The need for evidence based teaching has become an important ideology for nurse educators who are frequently encouraged to expand their teaching strategies based on recent advances in technology and student learning styles. Traditional lecture is often preferred by students, yet the literature encourages case study methodology for the development of critical thinking. A pilot study was conducted comparing learning outcomes using two different teaching strategies: lecture and case study instruction. Recommendations for using case study as a teaching methodology are offered.
\end{abstract}


Key Words: Case study, lecture, teaching methodologies, evidenced-based teaching 
Toward Evidence-Based Teaching: Evaluating the Effectiveness of Two

Teaching Strategies in an Associate Degree Nursing Program

Nurse educators are being encouraged to transition to new teaching and learning paradigms to meet expanded needs and learning styles of students as well as requirements of technological advances (Amerson, 2006; Hoffman, 2008; Sholvein, Huston, Fox \& Damazo, 2005). New methodologies such as problem-based learning support an active student role in learning and assist students to move from a basic understanding of information at the knowledge and comprehension levels to a higher level of understanding. Other research has found no strong correlation about the effectiveness of lecture compared with other methods. Some studies have found no significant difference in objective measures of learning by problem-based learning versus learning by lecture (Beers, 2005).

For nurse educators, critical thinking has become a benchmark of how students perform and are evaluated, and is the the foundation judging competence in clinical practice (DiVitoThomas, 2005). Nursing research evaluating the development of critical thinking in novice nursing practice and nursing students is limited. The continual struggle by nurse educators to improve critical thinking demonstrates the need for innovative teaching interventions that aid in the development of critical thinking as student nurses enter into practice (Forneris \& PedenMcAlpine, 2007). Teaching through case study is regarded as a superior teaching methodology when compared with lectures in promoting a learner's critical thinking skills (Kim, Phillips, Pinsky, Brock, Phillips, \& Keary, 2006). Many educators feel lecturing does not provide for critical thinking, application of knowledge, or active problem-solving, but given constraints of time, class size, efficiency, effectiveness and comfort, the traditional lecture is the only logical choice (Delpier, 2006; Mikol, 2005). 


\section{Traditional Lecture}

The traditional lecture presentation is perhaps the most well-known and often-used teaching strategy, but one that recently has come under scrutiny as to effectiveness and appropriateness (Di Leonardi, 2007). As a teaching strategy, the traditional lecture is one to which most students have adapted throughout the educational process to provide them with the necessary information for their classes. Further, experience indicates that students have an increased comfort level with this traditional teaching methodology partly because they can remain in a passive role. Students report a preference for receiving didactic instruction that provides the information they believe they need to know. Many students indicate a decreased comfort level with nontraditional teaching methods because of a need to be prepared, become an active participant, and change their role from passive to active learner (Delpier, 2006).

While many nurse educators cite traditional lecture as the most effective teaching methodology in terms of preparation time, class size, efficiency, and personal comfort (Delpier, 2006; Mikol, 2005), they continue to search for more effective ways of teaching (Martens \& Stangvik-Urban, 2002). However, the literature supports the use of lecture as an effective teaching methodology and considers benefits such as clarification of difficult concepts, organization of thinking, and promotion of problem solving (Naismith \& Steinert, 2001). If the lecturer can successfully reframe the delivery from being strictly one-way communication and engage learners, then it can be a successful tool in the learning process (Di Leonardi, 2007). Similarly, with the appropriate delivery, Bain (2004) supports a "modified" lecture as appropriate for clarification and simplification of difficult material and inspirational for students, but warns that the best educators do not rely solely on lecture for instruction. A quasiexperimental study by Baumberger-Henry (2005) demonstrated no significant difference in learning between cooperative learning, case study, and lecture. However, the study showed that 
students in the case study and cooperative learning groups did report better self-perception of their problem-solving and decision making skills.

\section{Case Study}

Some literature supports interactive teaching methodologies as promoting increased understanding and application of knowledge as well as retention of factual knowledge (Costa, Rensburg, \& Rushton, 2007). Although case studies have been used as educational tools for over 100 years in a variety of disciplines, a dearth of information exists in the research nursing literature regarding their use, construct, and outcomes (Delpier, 2006). Indeed, among the multiple alternative teaching methodologies now in existence including case studies, minimal research has been conducted in regard to their specific integration into curricula and expected outcomes in nursing education. The few additional offerings available are limited to examples, direction, and support of, or for, the individual method employed. Delpier (2006) contends that student reluctance to participate and lack of attention, and faculty insecurity and time requirements are among the disadvantages of case studies.

Despite this implication that case studies have not been well-received by students or faculty, the literature indicates that case studies are an effective teaching strategy that involves students, allows for an alternative learning environment, and provides an opportunity for students to apply knowledge, evaluate learning needs, hone problem-solving skills, and critically evaluate resources (Lonser, Abbott, Allen, \& Davidhizar, 2006). Case study as an interactive teaching methodology requires students to become active learners, think critically, and extend classroom knowledge into the clinical realm (Draude, 1996). Henning, Nielsen, and Hauschildt (2006) present a descriptive analysis of how educators can transition their courses from lecture-based to a case-study approach. A map is provided showing educators how, when, and to what degree they can involve students in positive learning outcomes. Additional benefits of case studies 
include improved group interaction through open dialogue, added rapport within the classroom to enrich the learning environment, and a more memorable experience (Herrman, 2002). Ciesielka (2003) found the use of case studies in teaching elicited a very positive response from students who found the exercises to be stimulating and motivational.

Background and Purpose of the Research Study

Questions arise when considering the most effective teaching strategies for student learning (Salsali, 2005). In fact, a paucity of nursing education research focusing on specific teaching strategies that promote student learning and critical thinking exists (Schaefer \& Zygmont, 2003). McCartney and Morin (2005) point out that the focus of recent nursing research has been skewed toward evidence-based clinical practice and away from investigations into how and what we are teaching or "evidence-based teaching". The consequences of this shift in focus have been a discontinuation of nursing education research offerings by several journals, a decrease in the availability of expert reviewers, and ultimately a decrease in funding for such endeavors. As a result, few answers exist regarding the most effective teaching skills and strategies in use today.

The purpose of this pilot study was to compare learning outcomes between two groups of students in an Associate of Science in nursing degree program using two teaching methodologies: lecture and case study instruction. A secondary purpose was to provide preliminary data for nurse educators to move towards evidence based teaching.

\section{Methods}

A quasi-experimental design was selected to conduct the study. The Thomas Jefferson University Institutional Review Board (IRB) was consulted and approval for the study obtained. A convenience sample of 48 ASN students completing their third semester of a four semester program were invited to participate in the study. Thirty-eight students signed an informed 
consent form after which each student independently completed the Visual, Aural, Read/Write, Kinesthetic (VARK) learning style self assessment (Fleming, 1995) on-line and a demographic questionnaire which was developed by the researchers. Table 1 displays selected student demographics related to gender, age, number in household, hours worked per week, previous education and learning style characteristics.

Students were enrolled in either the Nursing Care of Children (Pediatric Nursing) course or Nursing Management of Adults with Neurologic/Sensory and Psychosocial Behavioral Disorders (Neuro-Psych Nursing) course. Randomization of groups for study participation did not occur. For the first seven weeks of the semester, students in both courses received didactic content related to course objectives via lecture. Lectures using PowerPoint ${ }^{\circledR}$ were developed by the individual course instructors. Three topics in each course were selected for study and learning outcomes. The study topics in the Pediatric Nursing course were cystic fibrosis, sickle cell disease, and diabetes mellitus. Neuro-Psych Nursing study topics included schizophrenia, cognitive disorders, and eating disorders. Students completing Pediatric Nursing in the first seven weeks of the semester then progressed to Neuro-Psych Nursing. Likewise, those completing Neuro-Psych Nursing then progressed to Pediatric Nursing.

During the second seven weeks of the semester students received didactic content either via lecture or through case study. Peer reviewed case studies were obtained from published and public domain resources. Six case studies were delivered in lieu of lecture for study topics previously identified in the first seven week courses, specifically, cystic fibrosis, sickle cell disease, diabetes mellitus, schizophrenia, cognitive disorders, and eating disorder topics. Learning outcomes for both case study and lecture were measured via objective testing using the same NCLEX style question exam. 
Because the aim of the study was to determine which type of teaching method (lecture versus case study) yielded higher test scores, the study design treated the sample as two independent groups of students receiving both teaching methods. Group 1 had 3 one-hour lectures on Neuro-Psych Nursing followed by 3 one-hour case studies on Pediatric Nursing. Group 2 had 3 one-hour lectures on Pediatric Nursing followed by 3 one-hour case studies on Neuro-Psych Nursing. Each class had three tests on various sub-subjects within the class.

In addressing the aim of the study, the researchers proceeded from the simple to the complex, beginning with descriptive and bivariate analyses and culminating in multivariate modeling. Analyses were guided by the following principles. First, descriptive and simple analyses were conducted to ensure that more complicated, model-based analyses reflect the empirical data. Second, models were selected to accommodate the response measurement scale, data structure, and scientific objectives. Third, multiple findings were evaluated for coherence and sense according to scientific plausibility, rather than by focusing on individual p-values.

Frequency distributions for each of the two groups were compared using Fisher's exact tests. A logistic regression was used to derive a propensity score for group assignment to be used to control for group differences in future regression modeling. The propensity score was stratified into five quintiles based on rank of likelihood of belonging to Group 1. Raw test scores were compared using a two-sample t-test. To determine if the test scores are related to teaching style, repeated measures models (Proc Mixed in SAS) were constructed for each class (i.e. separate models for Pediatric Nursing and Neuro-Psych Nursing). This model included fixed effects for the primary independent variable (teaching type) and fixed effects to control for the sub-subject test, the stratified propensity score, and the overall score for the other class. Random effects were included to control for within student correlation (i.e. repeated measures for each student). All statistical tests were two-sided and $\mathrm{p}<.05$ was considered significant. SAS 
(Statistical Analysis Systems, version 9.1; Cary, NC) was used for data manipulation and statistical analysis.

Results and Findings

A significant difference between group demographics was found in hours worked per week $(\mathrm{p}=.0044)$ and in the type of learner $(\mathrm{p}=.0077)$ as reported in Table 1 . However, other demographic comparisons between groups were not statistically significant. Given that the data suggest that the groups may be different and because the students were not randomly assigned to the groups, a propensity score was created based on a subset of the characteristics. Age, gender, number in household, number of work hours, previous education, and learning style characteristics were used in the propensity score model.

The average raw test scores for each sub-test and an overall score (i.e. the average of the 3 sub-tests) suggest that lecture resulted in higher scores for Pediatric Nursing but case study resulted in higher scores for Neuro-Psych Nursing with some differences between groups reaching statistical significance. In each case, Group 2 had the higher scores (see Table 2). However, as shown in Figure 1, after controlling for the propensity score and the overall Pediatric Nursing score, there was no significant difference between Neuro-Psych Nursing scores using the case study (adjusted mean overall score $=88.0$ ) as compared to lecture (adjusted mean overall score $=87.2 ; \mathrm{p}=0.83)$. Similarly, after controlling for the propensity score and the overall Neuro-Psych Nursing score, there was no significant difference between Pediatric Nursing scores using the case study (adjusted mean overall score $=74.3$ ) as compared to lecture (adjusted mean overall score $=79.3 ; \mathrm{p}=.26$ ).

There was no significant difference between teaching methods for Pediatric Nursing $(\mathrm{p}=0.26)$ or for Neuro-Psych Nursing $(\mathrm{p}=0.83)$. 


\section{Limitations}

There are several limitations related to this study. The confines of a pilot study including small sample size and use of a convenience sample of subjects without random selection into the two groups are given limitations. Two different faculty members presented case studies in two subject areas and their individual teaching styles and delivery of case study content may have impacted the results. Test questions were selected from standardized test banks to bolster validity and reliability; however, specific data on the test questions is not available. KuderRichardson scores were obtained for each examination and point bi-serial coefficients analyzed for each question.

\section{Discussion}

Although this study's results show no significant differences in learning outcomes between lecture and case study teaching methods, it could be argued that integrating case study methods into didactic instruction is of importance as nurse educators continue to strive to find ways to enhance student learning. Some literature shows that the case study method promotes critical thinking. Consequently, nurse educators should ask, "Why not teach using case studies if it is known the case study teaching method improves critical thinking, and using this approach promotes learning beyond that of a satisfactory test score?"

Additional research for evidenced based teaching should investigate the effectiveness of other alternative teaching methodologies. There is limited research comparing multiple methodologies with learning outcomes. Specific factors that affect various teaching methods need to be explored. For example, does case study utilization have better outcomes when utilized at a later point in a nursing curriculum? At what point does a student's knowledge level warrant use of case study methodology? Educators and students will benefit from continued research in this area. 
Although study results cannot be generalized, the findings and conclusions drawn from this study are significant to nurse educators in academe, employers, and the public. First, nurse educators who integrate case studies into the classroom will benefit as students should have the same learning outcomes but additionally will develop critical thinking skills with the potential for increased NCLEX scores. Second, employers and the public will benefit when new graduates enter the workforce more fully prepared to apply critical thinking skills to complex patient care situations, and have the requisite experience to work more collaboratively in a group setting. 


\section{References}

Amerson, R. (2006). Energizing the nursing lecture: Application of the theory of multiple intelligence learning. Nursing Education Perspectives, 27, 194-196.

Bain, K. (2004). What the best college teachers do. Cambridge, MA: Harvard University Press. Baumberger-Henry, M. (2005). Cooperative learning and case study: Does the combination improve students' perception of problem-solving and decision making skill? Nurse Education Today, 25, 238-246.

Beers, G.W. (2005). The effect of teaching method on objective test scores: Problem based learning versus lecture. Journal of Nursing Education, 44, 305-309.

Ciesielka, D. (2003). Clues for clinicians: A case-study approach to educating the renaissance. Nurse Educator 28, 3-4.

Costa, M.L., Rensburg, L.V., \& Rushton, N. (2007). Does teaching style matter? A randomized trial of group discussion versus lectures in orthopedic undergraduate teaching. Medical Education, 41, 214-217.

Delpier, T. (2006). Cases 101: Learning to teach with cases. Nursing Education Perspectives, 27, 204-299.

Di Leonardi, B.C. (2007). Tips for facilitating learning: The lecture deserves some respect. The Journal of Continuing Education in Nursing, 38, 154-161.

DiVito-Thomas, P. (2005). Nursing students stories on learning how to think like a nurse. Nurse Educator, 30, 133-136.

Draude, B. J. (1996). Use of master classroom technology to implement a case study approach to learning. Paper presented at the 1996 Proceedings of the Mid-South Technology Conference. Retrieved June 23, 2008 from http://www.eric.ed.gov/ERICDocs/data/ ericdocs2sq1/content_storage_01/0000019b/80/14/c1/88.pdf 
Fleming, N. (1995). I'm different; not dumb. Modes of presentation (VARK) in the tertiary classroom. In A. Zelmer (Ed.), Research and Development in Higher Education, Proceedings of the 1995 Annual Conference of the Higher Education and Research Development Society of Australasia (HERDSA), Australia, 18, 308 - 313. Retrieved March 2, 2009 from, http://www.vark-learn.com/documents/different_not_dumb.pdf

Forneris, S. \& Peden-McAlpine, C. (2007). Evaluation of a reflective learning intervention to improve critical thinking in novice nurses. Journal of Advanced Nursing, 57, 410-421.

Henning, J., Nielsen, L., \& Hauschildt, J. (2006). Implementing case study methodology in critical care nursing: A discourse analysis. Nurse Educator 31, 153-158.

Henry, P. (2006). Making groups work in the classroom. Nurse Educator, 31, 26-30.

Herrman, J. (2002). The 60 second nurse educator: Creative strategies to inspire learning. Nursing Education Perspectives, 23, 222-227.

Hoffman, J. (2008). Teaching strategies to facilitate nursing students' critical thinking. Annual Review of Nursing Education, 6, 225-236.

Kim, S., Phillips, W., Pinsky, L., Brock, D., Phillips, K., \& Keary, J. (2006). A conceptual framework for developing teaching cases: A review and synthesis of the literature across disciplines. Medical Education, 40, 867-876.

Lonser, V. M., Abbott, R., Allen, K., \& Davidhizar, R. (2006). Implementation of problem-based learning in a final semester comprehensive nursing course. Health Care Manager, 25, 184-193.

Martens, K. \& Stangvik-Urban, L. (2002). Views on teaching-learning: Lessons learned from nursing education in Sweden. Nurse Educator, 27, 141-146. 
McCartney, P.R. \& Morin, K.H. (2005). Where is the evidence for teaching methods in nursing education? The American Journal of Maternal/Child Nursing, 30, 406-412.

Mikol, C. (2005). Teaching nursing without lecturing: Critical pedagogy as communicative dialogue. Nursing Education Perspectives, 26, 86-89.

Naismith, L., \& Steinert, Y. (2001). The evaluation of a workshop to promote interactive learning. Teaching and Learning in Medicine, 13, 43-48.

Salsali, M. (2005). Evaluating teaching effectiveness in nursing education: An Iranian perspective. BMC Medical Education, 5(29). Retrieved June 23, 2008 from http://www.biomedcentral.com/1472-6920/5/29

Schaefer, K. M., \& Zygmont, D. (2003). Analyzing the teaching style of nursing faculty: Does it promote a student-centered or teacher-centered learning environment? Nursing Education Perspectives, 24, 238-245.

Shovein, J., Huston, C., Fox, S., \& Damazo, B. (2005). Challenging traditional teaching \& learning paradigms: Online learning \& emancipatory teaching. Nursing Education Perspectives, 26, 340-343.

Smith-Strøm, H. \& Nortvedt, M.W. (2008). Evaluation of evidence-based methods used to teach nursing students to critically appraise evidence. Journal of Nursing Education, 47, 372375. 